\title{
Removal of American Indians, destruction of Ottoman Armenians. American missionaries and demographic engineering
}

Hans-Lukas Kieser

\section{(2) OpenEdition \\ Journals}

Electronic version

URL: http://journals.openedition.org/ejts/2873

DOI: $10.4000 /$ ejts.2873

ISSN: $1773-0546$

Publisher

EJTS

\section{Electronic reference}

Hans-Lukas Kieser, «Removal of American Indians, destruction of Ottoman Armenians. American missionaries and demographic engineering », European Journal of Turkish Studies [Online], 7 | 2008, Online since 05 March 2015, connection on 16 February 2020. URL : http://journals.openedition.org/ ejts/2873 ; DOI : 10.4000/ejts.2873 


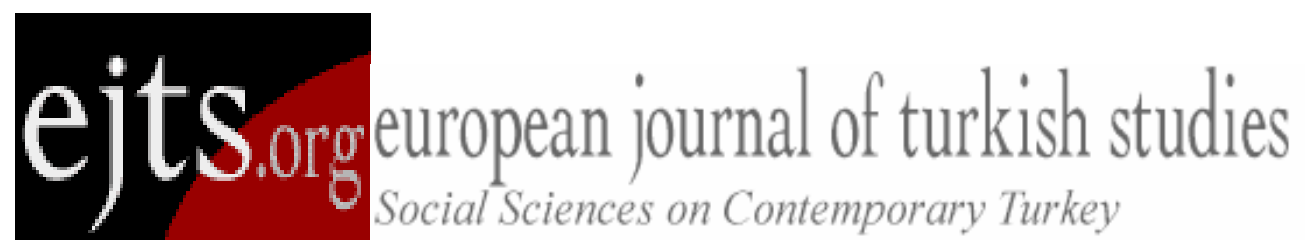

Kieser, Hans-Lukas (2008) 'Removal of American Indians, destruction of Ottoman Armenians. American missionaries and demographic engineering', European Journal of Turkish Studies, Thematic Issue N 7, No. 7 | Demographic Engineering - part I, URL : http://www.ejts.org/document2873.html To quote a passage, use paragraph (§).

\title{
Removal of American Indians, destruction of Ottoman Armenians. American missionaries and demographic engineering
}

\author{
Hans-Lukas Kieser
}

\begin{abstract}
This article describes and compares two distinct instances of removal of a people from its native land. The removals in question were organized at different times by two different states, one a rising, the other a crumbling power. The removals had different dimensions, but were both claimed to be unavoidable for state building. The same organization, the American Board of Commissioners for Foreign Mission (ABCFM), was a privileged witness and an outspoken critic of both: the removal of the American Indians from Georgia and Carolina in the 1830s, and the removal of the Armenians from Asia Minor during World War I. This removal comprised nearly all Ottoman Armenians, equaled mass murder and paved the way for an exclusively Turkish nation-state in the whole of Anatolia. In both cases the ABCFM had defended an integrative, nonexclusive vision of the societies concerned.
\end{abstract}


'If we abstract from the human aspect, the exclusion of the Armenians from the body of their [Turkish] state was no less a constraining necessity than [...] was the extermination of the Indians for the new state of the white people in America.'

Dagobert von Mikusch, Gasi Mustafa Kemal zwischen Europa und Asien. Eine Lebensgeschichte, Leipzig: Paul List, 1929, p. 83.

'Hundreds of men lie dying, dead; Brothers of ours, though their skins are red; Men we promised to teach and feed. $\mathrm{O}$, dastard nation, dastard deed!'

Walter N. Wyeth, Poor Lo! Early Indian missions. A memorial, Philadelphia Pa.: W.

N. Wyeth, 1896, frontispiece.

The removal of 'non-assimilable' groups by states in the 19th and 20th centuries obeyed, or claimed to obey, a rationale of state building and social engineering. It was said to be necessary for the survival or optimized functioning and unavoidable modernizing of the national society. Removal led to traumatic consequences for the removed group and was often criticized or even denounced as criminal by contemporaries who held alternative visions of their society's future. Removal raised ethical questions which, by referring to law, truth, humanity and religion, challenged both the permissibility and the long-term wisdom of that kind of policy. Before being removed, the targeted groups were classified and registered, mostly according to ethno-religious criteria, on the basis of existing data or new census lists.

[2] This article describes and compares two distinct instances of removal of a people from its native land. The removals in question were organized at different times by two different states, one a rising, the other a crumbling power. The removals had different dimensions, but were both claimed to be unavoidable for state building. The same organization, the American Board of Commissioners for Foreign Mission (ABCFM), was a privileged witness and an outspoken critic of both: the removal of the American Indians from Georgia and Carolina in the 1830s, and the removal of the Armenians from Asia Minor during World War I, comprising nearly all Ottoman Armenians, and paving the way for an exclusively Turkish nation-state. In both cases the ABCFM had defended an integrative, non-exclusive vision of the societies concerned. The ABCFM was an important interdenominational organization backed by Protestant churches in New England and beyond. It reached a large Protestant public in the USA and in Europe through its publications, became a leading part of what historians have called the non-governmental internationalist 'Protestant International' of the 19th century (Jenkins 2000), and made its main investment in the late Ottoman world (Grabill 1971). 
[3] The second half of this article questions the role of witnesses, and the value of discourses at odds with what rulers, the elite and most people at the time accepted as unavoidable rationales of historical progress, even if later generations condemn them. The Indian removal did not equal mass killing as did that of the Armenians. Nevertheless, this article argues that modern state building was ambivalent about demographical engineering not only in Turkey, but also, even if less apparently, in the USA. In the 19th and 20th centuries, ethno-religious diversity was explored, appreciated, and projected into a modern universalistic future where legal equality, nationally or globally, would reign. This was the project of an enlightened modernity; in the Ottoman Empire this was, at least partly, the project of the Reform Age (Tanzimat). However, at the same time, modern states exercised discrimination and engineered social Darwinist exclusion on the basis of ethno-religious distinctions and systematically gathered data. To reveal and to argue against such powerful state rationales was a difficult challenge both in the 1830s in the USA and the 1910s in Turkey. In Turkey it still remains difficult.

\section{American Indian Removal}

[4] In 1838-39 large parts of the Indian tribe of the Cherokees in Northern Georgia and South Carolina were forcibly relocated, some of them in manacles. About 4,000 out of ca. 16,000 relocated people died during the 116-day forced journey to 'unorganized territory' West of Missouri, now Oklahoma, over a distance of ca. $1000 \mathrm{~km}$. This was the so-called Trail of Tears, the particularly deadly archetype of several Indian removals from Florida, Georgia, Alabama, South Carolina and Mississippi in the 1830s. In total they involved about 100,000 Indians of which many thousands died; many more could not cope with the trauma and began, for generations, a life in misery and alcoholism. 'Heart-sick and weary, they never became reconciled to their lot,' Rev. Walter N. Wyeth wrote in 1896 (Wyeth 1896: 168).

[5] Theoretically at least, a voluntary removal with due compensations would not have infringed human rights. However, the Indian Removal Act of 28 May 1830 was a departure from the policy of respecting the established rights of the Indians. It authorized the government to grant Indian tribes western prairie land in exchange for their territories, especially in the Southeast. Nevertheless, it provided only for negotiation and voluntary 
relocation, not for coercion and violence, as happened in 1838-39. A group of Cherokee had already voluntarily left its land in 1835-37 (Thornton 1990: 63-77; Carter n.d.). The Indian tribes did not become citizens of the USA until the 1920s. The Armenians, for their part, were citizens of the state that removed and killed them. There were no negotiations with representatives of the Armenian community in or before 1915 about a territorial exchange and the destination of the removed people.

[6] Former general Andrew Jackson, the seventh US President (1828-36), implemented Indian removal as a top priority of his presidency. Jackson is regarded as the man who established modern mass democracy combined with strong popular presidency in the USA; he left a 'vigorous and well-organized Democratic Party as a legacy' (Bradley 2008). Ironically, since Jackson's egalitarian mass democracy was not sufficiently tied to constitutional human rights, it hurt both the anti-removal and anti-slavery movements of the time. 'Most new voters in the South and the West wanted Indian removal. Most new voters in the South wanted slavery' (Heidler 2007: 30).

[7] A democrat and a demagogue, Jackson was the model of an American nationalist. He had experienced the American Revolution and was a military hero, having crushed the Indian tribe of the Creeks in 1813-14. He perceived the Indians as erratic, inferior to the white settlers and a threat to the national integrity of the young USA. This all the more as many tribes had believed that Great Britain was more likely to respect Indian property; they had been on the 'wrong side' during the American Revolution and its wars. Indian attacks had already been a hard reality for many settlers before and after those wars. Settler militias in turn were mostly rapacious and brutal. They ultimately proved to be a major instrument to hasten removal; governors had only partial control of them (Hill 2005: 61). In contrast, the Young Turk rulers of the 1910 s feared the Armenian as educationally superior rivals, not as 'savages.' In fact, compared to armed Indian resistance as a whole, Armenian resistance was weak since Armenians, in contrast to the Indians, did not generally bear arms.

[8] The Trail of Tears, however, did not concern 'savages' but, significantly, a tribe among the so-called Five Civilized Tribes. The Cherokees had managed to adapt their way of life in many respects to that of the white men, including, in some instances, slavery. They introduced European know-how, were successful farmers, formed a tribal government modelled on the US government, developed an alphabet for their own Iroquoian language in 
1821 and very quickly became literate (Wishart 1995: 134).

[9] Three aspects proved to be relevant factors of Cherokee removal: their regional autonomy, their wealth in terms of cultivable land and gold, and their success in finding their own, semi-autonomous path in modern America. Jackson's Indianophobia and his fear that the Southern states would secede if he opposed them accorded with the expansive greed of white Georgia in the 1820s and 1830s, with Georgia's will to be the only master of the territory, the pressure of its settlers, the suspicion that the Cherokees were a fifth column, and the missionaries to the Cherokee agents of the North (Andrew 1992: 153). In Turkey, in the more turbulent 1910s, analogous elements (greed, fear, the pressure of Muslim migrants, Turkist claims to Anatolia, 'treacherous' Armenian outside relations), but on a much larger scale, spoke against the Armenians.

[10] President Jackson feared that 'independent, sovereign Indian nations would prove easy prey for manipulation by hostile powers.' Anachronistically or not, removal was in his view 'the only way to safeguard the Constitution of the United States and the nation's survival,' Sean Wilentz, a US historian close to the Democratic Party establishment, states in his recent book on Jackson. Wilentz calls Jackson's removal policy insidious and ruinous for the Indians, but 'neither genocidal nor far-fetched' (Wilentz 2005: 68-69). Historian Harold Bradley considers the fact that Jackson failed to comply with the Supreme Court's decision to implement federal authority in Georgia in favour of the Cherokees, an 'indelible stain' on his record. The Supreme Court had ruled against Georgia in this issue, but Jackson sympathized with Georgia's local government and enforced, after years of anti-Indian harassment, the Indian Removal Act of 1830.

[11] In December 1828, just after Andrew Jackson's election, the state of Georgia had extended its jurisdiction to Cherokee land, on which gold had been discovered. This land, which belonged to the Cherokees according to a treaty, was now mapped out for distribution to white citizens of Georgia. In — not only retrospectively — racist terms, the new Georgian jurisdiction forbade, among other discriminations, Indians to be 'a witness or party in any suit where a white man should be defendant' and any contract between a white man and an Indian without testimony of two white witnesses. The purpose was to 'render life in their own land intolerable to the Cherokee' and plunder them, as the anthropologist James Mooney (1861-1921) stated. In the years just before the final Trail of Tears, bands 'of armed men 
invaded the Cherokee country, forcibly seizing horses and cattle, taking possession of houses from which they had ejected the occupants, and assaulting the owners who dared make resistance' (Mooney [1897-1898] 1996: 118). In the years before the Armenian genocide, the question of Armenian agrarian property, robbed by Kurds, was one of the main issues of Ottoman interior politics. Needing the cooperation of the tribal chiefs, the Young Turks were not able, and finally not willing, to resolve this issue according to the rule of law.

[12] Beside acts of individual and collective Indian resistance, a major obstacle to removal, both on the local and the national level, was the ABCFM. This first US overseas mission had begun its work among the Cherokees in 1816, six years after its foundation in Boston in 1810, and three years before it sent its first missionaries to the Ottoman Empire. Yet in 1969, the historian Clifton J. Phillips called that mission a 'brilliant, but practically unknown, chapter in the history of the American frontier' (Phillips 1969: 61). The early ABCFM's American Indian mission founded churches and schools 'in the wilderness.' It identified with the oppressed. 'Will any bring it to the bar of God, when these wretched Indians point to us, as the cause of their ruin,' Levi Parsons - in 1819 the first American missionary to the Ottoman Empire - wrote in his diary when he was still a student at Andover/Harvard. 'Reason, religion forbids' (Parsons 1830: 42). When in 1818 the Cherokees negotiated a new treaty 'giving up a part of their ancestral domains,' the ABCFM secretary 'hurried to Washington and helped insure the inclusion of a clause granting the Indians perpetual rights to their remaining tracts in the South' (Phillips 1969: 70).

[13] In a significant way, Indians had been and were the 'others' within American society. After an initial policy of assimilation focusing on teaching English, which the missionaries thought would help the Indians to survive, they adopted a more integrative approach. They promoted the vernaculars and a bilingual Cherokee-English newspaper. They attempted to bring to the Cherokees the best of what they believed to have and to know. Since the Cherokees shared in this they were equals not only according to the principle of human equality, but also as fellow believers in the Gospel. For the ABCFM, race and culture could not be a factor of discrimination; material envy obviously not. Moreover the Cherokees' visible 'progress in civilization' and acquisition of wealth spoke against all those who despised Indians as inferior. Against the prejudices of many Yankees, the ABCFM defended marriages between Whites and Indians in the 1820s. 
[14] This test in antiracism, however, was easy compared to what Jeremiah Evarts, the leading ABCFM secretary in 1821-31, considered the decisive test for the young US society: to resist forcible Indian removal. This was for him a struggle 'for the soul of America,' that is, for what he patriotically believed to be the 'manifest ethics' of the American project. Evarts, together with the missionaries on the spot, sympathetic publishers in New England, and some politicians in Washington, led an extensive fight against the removal policy of the Jackson administration after 1828. Under the pseudonym of William Penn he wrote a series of articles that were printed by several papers and cited in Congressional debates (Evarts 1981: 3-40). Despite these efforts, the Congress passed Jackson's bill for Indian Removal in May 1830.

[15] Evarts continued the fight. 'The people of the United States are bound to regard the Cherokees and other Indians, as men; as human beings, entitled to receive the same treatment as Englishmen, Frenchmen, or ourselves, would be entitled in the same circumstances. Here is the only weak place in their cause. They are not treated as men; and if they are finally ejected from their patrimonial inheritance by arbitrary and unrighteous power, the people of the United States will be impeached,' he wrote in one of his last essays of November 1830, always signed 'William Penn' (Evarts 1981: 282). Not human rights, but the rights of the stronger seemed to win. Evarts died, exhausted, in May 1831 (Andrew 1992: 262).

[16] At the end of 1830, Cherokees and missionaries held a meeting at Cherokee New Echota and adopted resolutions against removal. Staying on Cherokee territory without permission by Georgian authorities, the ABCFM missionaries Samuel Worcester and Elizur Butler were imprisoned. The ABCFM and those it had won for its cause in Washington supported their appeal to the Supreme Court. On 3 March 1832, Chief Justice John Marshall declared the Cherokee Nation to be a distinct community outside the jurisdiction of the State of Georgia and cleared the prisoners of all charges (Phillips 1969: 72). In contrast, the Armenians were both citizens of the state and members of a distinct community, or millet (see below), and their millet, even if autonomous in certain regards, was within the territory and the main jurisdiction of the state.

[17] Understanding that Jackson favoured Georgia and wanted removal despite the Supreme Court, the missionaries finally recognized that their cause was lost, at least in the 
terms on which they had fought until then. Removal now seemed to be unavoidable. Recognizing this reality, the missionaries did not back those Cherokees who opted for armed resistance and killed the representatives of a minority Cherokee faction that had finally signed the pro-removal New Echota Treaty of 1835 (Phillips 1969: 74). The majority of the Cherokees remained in passive resistance.

[18] 'The soldiers came and took us from home,' a Cherokee woman recalled the eve of the Trail in autumn 1837:

[19] 'they first surrounded our house and they took the mare while we were at work in the fields and they drove us out of doors and did not permit us to take anything with us not even a second change of clothes, only the clothes we had on, and they shut the doors after they turned us out. They would not permit any of us to enter the house to get any clothing but drove us off to a fort that was built at New Echota. They kept us in the fort about three days and then marched us to Ross's Landing' (Hill 2005: 27).

[20] The main agent of the relocation was the army. The victims had been defined in 1835 by the first major census of Cherokees living in North Carolina, Georgia, Alabama, and Tennessee, compiled by the Federal government. It listed the name of the head of each family (Wishart 1995: 124-27; Carter n.d.). Total destruction, as in the case of the Armenians, did not occur. 'However tragic the removal of the southern tribes was, the tribes moved west under treaties that recognized them lands in the West in fee simple,' historian Francis P. Prucha concludes (Evarts 1981: 40). A number of Georgians were nostalgic, but they did not question themselves. 'The little cabins and wigwams of the Indians,' a white planter wrote in 1840, 'which are scattered about among the mountains and on the water courses from which they were driven and also the graves of their friends from which they were so unwilling to be removed makes one melancholy to look at, but still it was no doubt for all the best' (Hill 2005: 43).

[21] During the Trail of Tears the missionaries had accompanied the deportees. They rebuilt the missionary stations in the West (Phillips 1969: 72-73). But the deportation had broken the enthusiasm of a creative Cherokee renaissance in their homeland, and the ABCFM's fervour for the Indians subsided. Moreover, the political commitment against removal had not pleased all supporters of the ABCFM. Many of them preferred missionary 
news from overseas that reassured rather than troubled those at home. After the Indian Removal, the ABCFM concentrated more than ever upon its more promising overseas missions, in particular on those in the Ottoman 'Bible Lands.'

\section{Destruction of the Ottoman Armenians}

[22] The main facts, contexts and results of the destruction of the Armenians in Asia Minor during World War I have become common scholarly knowledge in the last few years (for recent narratives see Kévorkian 2006, Akçam 2006, Bloxham 2004; for the role of the ABCFM and other missions see Kieser 2000). I will limit my following observations to points relevant to the comparative perspective of this article and some lesser-known aspects of the question.

[23] The hierarchical difference between Muslims and non-Muslims was an established social fact of the Ottoman system, as was the distinction between Armenians, Rum and Jews according to their religious affiliation. These distinctions constituted the Pax Ottomanica and its hierarchical (not egalitarian) plurality. The religiously defined system of millets, i.e., autonomous communities, was thoroughly reformed after the Ottoman Reform Edict (Hatt-ı Hümayun) of 1856. The Western-inspired reforms of the Tanzimat (1839-1876), a synthesis of Ottoman institutions and Western norms, projected an Ottoman society that included semi-autonomous ethno-religious communities among which the Armenians were the most dynamically developing group. They experienced an educational boom and a cultural 'national renaissance,' and implemented the democratizing millet reform according to the HattI Hümayun. Most Ottoman Armenians were members of the traditional Ermeni Gregoryen milleti (or millet-i Ermeniyan). The small Protestant milleti, established in 1847 under the lead of the ABCFM, was mostly Armenian, and the seminal institutions of the ABCFM had a large Armenian clientele.

[24] Armenian men and women played a prominent role in late Ottoman literature, theatre, journalism, medicine, science, law, and commerce. In contrast to the Orthodox Ottomans (Rum) and the Christians of the Balkans, Armenians were called millet-i sadike, the 'loyal nation.' Armenians began to take on functions within the state of the Tanzimat; they imbibed Ottomanist ideas of a reformed, ethnically diverse and politically pluralist Ottoman 
state under the rule of modern law. They shared with the ABCFM an ideal of a pluralist, legally equal, and egalitarian society that stood in contrast to the hierarchical society of the preceding centuries. The American society that the ABCFM had hoped for would similarly have implemented Indian rights and citizenship, thus becoming a society whose egalitarian pluralism did not limit it self to white men.

[25] Unsurprisingly, the ABCFM strongly identified with the reforms of the Tanzimat and supported its Ottomanist vision, even if it looked more at its legal and social aspects than the reformers themselves, who were more concerned with restoring power. ${ }^{1}$ The ABCFM took seriously the equality of Muslims and non-Muslims which the Tanzimat and later the Young Turk Revolution of 1908 proclaimed. However, by empowering the Oriental Christians, the Tanzimat and the ABCFM contributed to Muslim resentment. Against this background and the losses in the Balkan, Sultan Abdülhamid II established his 'modern' but anti-egalitarian policy of Islamic unity in the late 19th century.

[26] American missionaries saw the problem of the Armenians in eastern Anatolia not as 'one of autonomy nor of any change of laws, but merely one of the enforcement of law.'2 They did not promote Armenian autonomy or independence, and took a clear stance against the revolutionary violence that newly founded Armenian organizations adopted when the promises of reforms in eastern Anatolia, made at the congress of Berlin in 1878 (Art. 61), failed to be implemented. But they agreed that if the Ottoman Government was chronically 'unable or unwilling to guarantee these loyal subjects such basal rights [security for life, property, and honour], then they must appeal to Europe to take measures to enforce the provisions of the Berlin treaty relating to security and order in these provinces' (The Orient, 22 Jan. 1913: 5). According to the ABCFM, the state withheld rightful protection to a group which it structurally discriminated; in particular, it yielded to the will of eastern Anatolian regional lords and rulers, great Muslim land owners and tribal leaders. In similar terms the ABCFM had protested the US government's unwillingness to impose federal law upon Georgia, its settlers and militias.

[27] The statistical struggle over the number of Armenians in eastern Anatolia had

1 The supranational ideology of 'Ottomanism' was 'perhaps the Tanzimat's most significant contribution to the empire' (Hanioğlu 2008: 106).

2 The Orient IV, No. 4, 22 January 1913, p. 5. 
begun after the Congress of Berlin (Kieser 2000: 121-23). Creeping unofficial 'removal' or coerced migration of Armenians was a reality during the period of Sultan Abdülhamid II (18761909), and was accompanied by Kurdification and resettlement of Muslim migrants from the Balkans and Caucasus. ABCFM sources mention over-taxation and direct threat as reasons for Armenian migration. ${ }^{3}$ How far Armenian removal in favour of Muslim settlers was a conscious policy of the palace has not been sufficiently researched. In any case, the largescale pogroms during the autumn of 1895 had a huge impact in terms of demography and property relations (Verheij 1999; Wiessner 1997). The ABCFM compiled comprehensive documentation of the anti-Armenian violence of the 1890s, contributing significantly to its international publicity and to the international humanitarian movement in support of its victims.

[28] Resolving the 'agrarian question,' the question of lost or stolen Armenian land, was a main issue of Ottoman politics after 1908, both nationally and internationally. The alliance between the Committee of Union and Progress (CUP) and the Armenian Dashnaktsutiun from 1907 was based on the consensus that the stolen land would be restored and safety for life and property established. However, after initial serious efforts by both CUP and Armenian representatives, the matter dragged on (Kaligian 2003: 85-106; Bozarslan 1997: 161-63). In 1912 Armenian representatives turned to European diplomacy. Outstanding cooperation between Russian and German leadership led to a substantial reform plan, which the Ottoman government signed in February 1914. For many international observers, including the ABCFM, these reforms - a thoroughly revised Russian draft - were a compromise which would bring more security and democracy to eastern Anatolia, and where no-one lost out (Davison 1990: 180-205).

[29] Since the Berlin Congress of 1878, the 'Armenian Question' and 'Armenian Reforms' had been discussed both in the Ottoman state and internationally, but never in terms of a possible removal. The projected modern reforms for a multiethnic eastern Anatolia aimed at guaranteeing first the safety and second the equality of the Armenians living there among a majority of Muslims (art. 61 of the Berlin Treaty and in particular the international Reform Plan of 1914). Nevertheless, the reform discussion had a demographic bias from the beginning. As early as 1879 , Captain Claytons, one of the British officers dispatched to eastern Anatolia 
after the Congress of Berlin, had thought about the possibility of making clearer ethnoreligious concentrations in Anatolia, for example the Armenians in the East, the Turks in the rest (Kieser 2000: 123). The Ottoman state of the Tanzimat reforms had not succeeded in improving the general safety in the mostly Kurdo-Armenian regions of eastern Anatolia. The equality of Muslims and non-Muslims in terms of law, taxes and legal practice, as promised in the Reform Edict, had only partly been implemented. Two serious attempts at concrete reforms according to art. 61 of the Berlin Treaty were finally signed by the Ottoman government in 1895 and 1914, but destruction followed in both cases.

[30] Analogously, President Jackson had implemented the Indian Removal shortly after and despite the decision of the Supreme Court in favour of Indian rights. Once the American state decided on removal and legislated accordingly, the ABCFM continued, at least for a while, to protest and denounce this policy as illegitimate because it violated fundamental human rights. The Deportation Act of May 1915 (a provisional law because the Ottoman Parliament was closed) made removal official. In contrast to the Indian Removal however, the Deportation Act disguised its target, range, methods and destination. From 1913 onwards, ABCFM members exposed the leading Young Turks as inexperienced and irresponsible young men who, intoxicated by imperial power and radical nationalism, might lead the Ottoman world into catastrophe and misuse Islam for purposes of mass violence.

[31] After a short period of Ottomanism after the Young Turk Revolution of 1908, in 1912-13 the CUP departed on a revolutionary right-wing policy based on the vision that Anatolia had to be made the national home of the Turks. Consequently, the CUP completely revoked the principles of the Tanzimat and went on to complete the destruction of the Armenians in Asia Minor. On 11 August 1916 the CUP abolished the community's National Constitution (Nizamname) of 1863, judging it to be the backbone of the late Ottoman Armenian dynamism that it perceived as menacing.

[32] The new Turkist approach to Asia Minor was based upon the demographic classification of the millet system. However, most data were to be found within the millet administration, which was linked to the ecclesiastical organization. Therefore the CUP regime needed much more statistical and ethnographical knowledge for the social engineering it was eager to undertake, and conducted studies before and during World War I (Dündar 2006: 63167). At the same time it led campaigns in order to demographically Turkify Anatolia. 
[33] In the spring of 1914, the CUP's Special Organization (Teşkilat-i Mahsusa) conducted boycott and terror campaigns against Rum, and expelled more than a hundred thousand Rum from the Aegean littoral; thus membership of the millet, i.e., religion, determined one's expulsion. The Armenian genocide of 1915 concerned above all the members of the Ermeni Gregoryen milleti. However, following ethno-religous and racial logics, it also included the much smaller numbers of Armenians in the Protestant milleti and Katolik milleti, even if exceptions were more frequent in these cases due to foreign pressure. As was to be the case for the Jews under Nazi rule, previous religious registration decided in final instance, not 'scientific' ethnic or racial tests. The Minister of the Interior Talat led the forceful demographic remodelling of Anatolia by telegraph.

[34] When general mobilization began in August 1914, an ABCFM member saw the government leading stupidly towards catastrophe:

[35]'Poor Turkey, poor Turkey, going it blindly, with a man at the head of the army, whose name is LIGHT [Enver], but he has certainly turned on the dark slide on his lantern, and is rushing headlong, pell-mell over the precipice, to sure destruction, was there ever such blindness?' (Mardin missionary doctor Daniel Thom quoted in Kieser 2000: 336).

[36] The CUP considered the Armenian appeal to European diplomats in 1912 an act of high treason. It judged the Dashnaktsutiun's refusal to conduct a (suicidal) guerrilla war against the Russians in the Caucasus side by side with the Special Organization in August 1914 in similar terms. Young Turk officers began to speak openly of the need to destroy the Armenian community although most Ottoman Armenian men served loyally in the army. Enver Pasha's disastrous defeat at Sarıkamış at the end of 1914 and his brother-in-law Cevdet's subsequent unsuccessful campaign in northern Persia led to high casualties, epidemics, and a brutal war on the Eastern Front. Several thousand young Armenians fled to Russian Armenia, most of them becoming volunteers in the Russian army. Contemporary Ottoman propaganda spread the thesis of a general Armenian rebellion in the spring of 1915.

[37] The first Ottoman victory at the Dardanelles 18 March 1915 saved the Young Turk leaders from depression and, according to the Austrian military attaché Joseph Pomiankowski, encouraged a 'brutal chauvinism' against Christians in general and Armenians in particular. Decisive meetings of the CUP central committee were held for which Dr. 
Bahaeddin Şakir, the head of the Special Organization in eastern Anatolia, returned to the capital. On 24 April, security forces began to arrest, torture and murder the Armenian elites in the whole of Anatolia, starting with Istanbul. On the same date, a telegram of the Minister of the Interior Talat to Cemal Pasha, Military Governor of Syria, announced that henceforth Armenians should be deported not to Konya, as had been the case with the Armenians from Zeytun, but to northern Syria. In a much more veiled language, without mentioning the Armenians, a provisional law published 1 June permitted the use of force against the population and mass deportations if 'national defence' was at stake. The main removal and deportation of the Armenians from eastern and western Anatolia and the province of Edirne towards the Syrian deserts was implemented from June to October 1915.

[38] In eastern Anatolia, men and youngsters were mostly massacred on the spot; those in the army were separated into labour battalions and killed. Women and children endured starvation, mass rape and enslavement during their marches. Deportations from the west included men, and the victims were transported partly by train. Several hundred thousand destitute deportees arrived in Syria in summer and autumn of 1915. In contrast to the Trail of Tears, they were not resettled as had been promised, but isolated in concentration camps and starved to death. Ali Fuad, the governor of Deir ez-Zor who attempted to help settle the deportees, was replaced in July 1916 by the hardliner Salih Zeki. Those who survived until the summer of 1916 were massacred, except for between a hundred and a hundred and fifty thousand whom Cemal Pasha had settled in southern Syria and formally converted to Islam. Widely varying numbers have been proposed, but the most reliable estimate is that more than half of the nearly two million Ottoman Armenians in 1914 were killed between 1915 and 1916 (Kévorkian 2006: 331-344). International holocaust and genocide scholars, beginning with Raphael Lemkin, have called that destruction a paradigmatic genocide of the 20th century.

\section{The ABCFM as a witness, a humanitarian, and a missionary of evangelical modernity}

[39] The ABCFM was antagonistic to the rulers of the US in the 1830s, but not to the point of breaking with the system. The ABCFM missionaries' encounters with CUP officials in 1915 were much more strained confrontations between opposing systems of reference and 
often different generations. Elderly Christian missionaries were faced with radical young men of action with strong anti-Christian resentments. In contrast to the USA of the 1830s, the young CUP leaders of the Ottoman Empire in 1914 were committed to a total war as allies of Imperial Germany. The destruction of the Armenians was determined within a conspiratorial single-party regime, not a democracy like the US in 1830. The ABCFM members were witnesses both in the 1830s and in 1915. But in the latter case, they could no longer identify with and struggle within the system of the rulers. The ABCFM had renewed its hope in the Ottoman world after 1908. It had hoped to play a leading role as social force of progress in a prospering young Turkey. But after the coup d'État in January 1913, after which the CUP established a single-party regime, the ABCFM lost almost all hope in the government (The Orient 29 Jan. 1913: 5). It no longer believed in any fundamental legal functioning of the Ottoman state. In such a situation, there was no place for public lobbying in the Ottoman capital in order to stop the whole scheme, as it had attempted in Washington 85 years before. Even if ultimately disappointed in its cause, the ABCFM of the 1830s had at least believed in the legal functioning of the US.

[40] The Americans closely observed the rulers and their actions in many places. The observation was particularly dense in Mamuretülaziz, where it led among many detailed reports to the establishment of a list of 52 local culprits (reproduced in Kieser 2000: 434-35). Henry Riggs, a teacher at the ABCFM's Euphrates Colleges, observed the transit camps of the deportees through a telescope during the summer 1915 and wrote that 'for most of the women and children was reserved the long and lingering suffering that massacre seemed to them a merciful fate - suffering such as was foreseen and planned by the perpetrators of this horror. I speak guardedly and state as a fact this horrid indictment of the Young Turks by whom the crime was committed' (Riggs 1997: 140).

[41] Another witness was Floyd Smith, a doctor who had been with the ABCFM in Diyarbekir since 1913. Right until the first weeks of Dr. Reshid's governorship, beginning in March 1915, Dr. Smith had enjoyed close relations with the government. He confirms the government's precarious position in view of the general problem of desertion before the arrival of Dr. Mehmed Reshid:

[42] 'The vali was superseded early in March. By getting a large force of police and gendarmes the new vali [Reshid] succeeded in apprehending the larger part of 
these men. He soon started the imprisonment of prominent Armenians using as justification the false statement that they were sheltering deserters. [...] Most people had weapons in their houses in remembrance of the event of twenty years ago, but I feel positive that there was no idea of a general uprising. About the first of April a proclamation was posted demanding arms. Men were imprisoned right and left and tortured to make them confess the presence and place of concealments of arms. Some went mad under the torture.'4

[43] Confessions were extracted under torture, so that an Armenian close to the ABCFM was made to sign an absurd document stating that the ABCFM was preparing an insurrection in Diyarbekir and that its agent, Dr Smith, was an Armenian. Dr. Smith was expelled before the final drama, the murder of the Christian population without, in this case, deporting them. The government confiscated the ABCFM's property in the city.

[44] The very rapid deterioration of the relations between local functionaries and the ABCFM, which had been present in the vilayet of Diyarbekir for three generations, was a strong sign of the 'new spirit' of social Darwinist engineering that the CUP emissary, the military doctor and vali Dr. Reshid, had brought with him to the eastern provinces in the spring of 1915. In applying the Law On Abandoned Property of 25 May 1915, Dr. Reshid founded a commission for the administration of the deportees' property. As in other places, instead of its declared goal of protecting the property and goods of the deported, the commission served to transfer it to the Muslim majority (Kieser 2002: 264-65).

[45] Thanks to its experience and its broad network of institutions throughout Asia Minor, the ABCFM understood early on the comprehensive nature of the single party regime's anti-Armenian policy that evolved in spring 1915. In many places missionaries were present during the first phase of the Armenian genocide, i.e., the massacres and removal in Asia Minor in 1915, much less during the second phase in 1916, when the survivors of the deportation were starved to death in camps, and the still surviving massacred, in northern Syria. ABCFM treasurer and informal head William Peet, in the 'Bible House' in Istanbul, was among the best informed persons of what was going on in the provinces and was in close 
Kieser, Hans-Lukas (2008) 'Removal of American Indians, destruction of Ottoman Armenians. American missionaries and demographic engineering', European Journal of Turkish Studies, Thematic Issue N ${ }^{\circ} 7$, No. 7 | Demographic Engineering - part I, URL : http://www.ejts.org/document2873.html html To quote a passage, use paragraph (§).

contact with members of both the German and the US Embassy. ${ }^{5}$

[46] Besides witnessing, missionaries on the spot could give some provisional material help and words of consolation; in some places, especially in Mamuretülaziz, they could help a number of individuals escape. On 14 July 1915 Peet cabled to Boston that there were many urgent calls, but that the ABCFM relief funds were exhausted. This led to the establishment of a humanitarian organization called Near Eastern Relief two months later (Kieser 2000: 34853). This organization supported the humanitarian resistance led by the Swiss teacher Beatrice Rohner in Aleppo in 1916-17, along with the ABCFM, the German organization Hilfsbund für christliches Liebeswserk im Orient, German diplomats, American diplomats, and Swiss connections in Aleppo and Basel. Partly protected by Cemal Pasha, Rohner built legal orphanages with local Armenians and communicated illegally with the deportees in the camps (Kaiser 2001). She was the only missionary who could write an extensive witness account of the second phase of the genocide (Kieser 2007: 219-34). Both in 1915 and 1838-39, ABCFM missionaries accompanied victims on their sad journey; although in the case of the Armenians only one missionary, Mary Graffam, among several who wanted to do so, was allowed to accompany the caravans, and only for a period of a few days (Harper 2003). Beatrice Rohner followed the deportees separately to Aleppo.

[47] In the 1830s and 1910s the ABCFM used its knowledge in order to inform a larger public, to lobby for the victims and to organize humanitarian help. At times, e.g. during the Balkan Wars in 1912-13, it also lobbied for Muslim victims, but could in that case not rely on a broader public in the West. The Near East Relief also supported needy Muslims. The ABCFM was an institution where a synthesis of Enlightenment and Evangelism, and corresponding educational, humanitarian and missionary strategies were attempted during more than a century.

[48] The differences between this approach and that of the governments the ABCFM criticized were not always clear-cut. They depended on protagonists, periods and places.

5 On 26 May 1915, when Armenian removal began, Peet wrote to US Ambassador Henry Morgenthau in the same city: 'I also enclose the document which you kindly handed me yesterday in regard to refugee Armenians who have been expelled from the Zeitoun region. I had a call this morning from Consul Mordtmann from the German Embassy, who came to deliver a message received through the German Consul at Erzroom from our missionaries at Erzroom asking for relief funds to aid the [Armenian] Christians who are now being expelled from Erzroom in pursuance of orders lately given. I am today telegraphing Lt.150.00 for this purpose' (quoted in Kieser 2000: 339). 
James Barton, the secretary of the ABCFM in the early 20th century, was closer to the US government and to American nationalism than Jeremiah Evarts, the leading ABCFM secretary during the struggle against Indian Removal. Men and women on the spot tended to be more universalist than missionary strategists or lobbyists at home. The feeling of Anglo-Saxon superiority or American exceptionality also existed among ABCFM members, in particular from the late 19th century onwards. Nevertheless, this was checked by a vibrant missionary internationalism and a critical attitude towards all forms of social Darwinism.

\section{Modernity, short-circuited and catastrophic}

[49] Coming back to the start: In sharp contrast to the American missionaries, for many German intellectuals of the Interwar Period, and not only for them, 'the exclusion of the Armenians from the body of their [Turkish] state was no less a constraining necessity than [...] was the extermination of the Indians for the new state of the white people in America' (Mikusch 1929: 83). Many European intellectuals of the interwar period admired the Republic of Turkey as an emerging modern, efficient Turkish nation-state, even if they knew quite well which kind of population politics had led to a Turkified Anatolia. In a short-term analysis they concluded that such demographic engineering was unavoidable for establishing a successful nation-state. The idea of an egalitarian plural society was nonsense to them. A 'healthy' and homogeneous nation-state, they came to believe, was incompatible with integrating a people that wanted to live and to assert its own ethno-religious identity, using the resources it legally possessed on its native soil.

[50] This conclusion from the CUP-Kemalist experience was relevant for German nationalists of the interwar period. Mikusch underlines his historical argument with an even more sweeping reference to the necessary 'extermination of the Indians,' thus blending relocation and extermination (Mikusch 1929: 81-84). Like Dagobert von Mikusch, some conservative American scholars today still stress 'inevitable' cultural clashes and the iron laws of modernity for both cases, calling at the most a 'tragedy' what contemporaries already had recognized to be an inhuman policy.

[51] 'In the end, the sad fate of America's Indians represents not a crime but a tragedy, involving an irreconcilable collision of cultures and values. Despite the efforts of well- 
meaning people in both camps, there existed no good solution to this clash. The Indians were not prepared to give up the nomadic life of the hunter for the sedentary life of the farmer. The new Americans, convinced of their cultural and racial superiority, were unwilling to grant the original inhabitants of the continent the vast preserve of land required by the Indians' way of life' (Lewy 2004).

[52] The discourse of constraint, realism, security and survival feeds forceful demographic engineering, and masks less commendable motives such as greed, racism, and intellectual laziness. Historically imprecise, it exonerates perpetrators from the responsibility of so-called historically determined clashes and destructions - even if one concedes that contemporary protagonists felt constrained (Kieser 2005). The Armenian destruction affected the whole of Asia Minor and more than ten times the number of persons that the Indian Removal of the 1830s impacted. More than half of the 'removed' Armenians were killed by systematic violence and by starvation. They were not, as were the Indians, resettled. Therefore, the Armenian removal was a comprehensive destruction of a targeted ethnoreligious group. In contrast, the Indian removal was initially only a relocation, but was nevertheless based on racism and greed and accompanied by massive 'collateral damages,' and led to destructive long-term consequences for the targeted group and its individuals. All this was indeed 'necessary,' as Mikusch argued, for the extensive establishment of a racial 'state of the white people.' Establishing a solid rule of law and overcoming slavery and racism was however more urgent for the future of this state.

[53] While in the case of the Armenians the argument of civilizational backwardness could not be proffered (they were the most eager and successful students of Western education in the Ottoman world), this argument was extensively used in the case of the Indians. But paradoxically, it was precisely the Five Civilized Tribes, which had largely settled down and were economically productive, who were first affected by removal in the 1830s. Beyond all their rhetoric, in both cases the men in power could simply not resist the temptation of destroying people they had the power to force. All the more so as such a coercive - in the Armenian case massively murderous - policy seemed to solve, once for all, old troublesome questions and erase disconcerting ethical challenges. Those responsible were either applauded or tacitly condoned by the majority of the population, who considered the removed people as 'others' and endless trouble makers. If we consider the difference between a World 
War context and a struggling but not deadly menaced rising settler republic, we see that some key elements of both cases were not very different, even if scale, handling, outcome and subsequent historical treatment were.

[54] Twenty years before it was implemented, the Indian Removal would have been seen as completely illegal and an improper topic for public discussion. This changed in the 1820s, when the pressure of the white settlers increased, gold was discovered and Andrew Jackson became president. Contrary to the Indian Removal, Armenian removal from Anatolia had never been discussed in advance, at least not publicly. Any public discussion of or allusion to such a huge scheme would have been both inconceivable in 'normal' times (in contrast to the times of total war) and contrary to the doublespeak that the late Ottoman government was accustomed to using in cases of mass coercion and violence.

[55] The point that his own state in its more or less normal functioning infringed fundamental rights particularly challenged Jeremiah Evarts's faith in America's future. It led him and his missionaries to concentrate their utopian energies on the ABCFM abroad, above all upon the Bible lands. The Cherokee mission, and with it the vision of a modern, prosperous, self-determined future of that part of US society on its ancestral soil, had been a crucial issue. With the failure of the ABCFM's Cherokee vision, a particularly sensitive test of American millennialism ${ }^{6}$ had failed in the USA itself. As a result, the ABCFM's work for the establishment of its millennialist visions in the Ottoman world became all the more important.

[56] From the beginning, the ABCFM had freed itself from the old Puritan idea that America was the 'promised land' or new Kanaan. Already in the 1810s it had set on the Ottoman world as the focal point of the global millennium, including the 'restoration' of a modern Israel. After a first pioneering, but unsuccessful phase focussed upon the Jews, the Armenians became central to the ABCFM's Near Eastern mission. Compared to its mission to the Indians, this mission was much more extensive, and had an internationalist scope. It included European collaborators and endeavoured at times to mobilize an international public. In both cases, it failed catastrophically in its attempt at initiating an evangelical and human rights-based modernity (Kieser 2007: 11-65). On the other hand, its legacy thoroughly calls to 
mind and questions the 'short-circuited' Realgeschichte of the demographically engineered establishment of modern states. 'Short-circuited' in the sense that sooner or later, subsequent generations need to admit and, where possible, readjust the coercive, forcible, and violent steps which their founding fathers believed to be unavoidable on the road towards the modern global age.

\section{Conclusion}

[57] Both for the Indian removal and the destruction of the Armenians, the ABCFM archives contain accurate reports of what went on. They form a crucial archival basis for the historical reconstruction of those events and their contexts. However, after both the 1830s and World War I, the ABCFM did not publish much and never really came to terms with it failure. This probably has to do with their limited chances of being heard in an American society that cultivated a 'culture of victory,' including religious triumphalism, and refrained from learning to cope with collective loss. The missionaries' handwritten or typed retrospectives have waited in the archives for international historians to come and deal with the issue. An impressive number of relevant papers from ABCFM archives have been published in the late 20th and early 21 st centuries.

[58] Utopian or not, biased or not, the ABCFM's voices need to be emphasized not only for the richness of their eyewitness reports, but because they opposed mass violence, including war itself. Accordingly they resisted any discourse that named policy 'tragedy' and forceful removal 'inevitable history' instead of what it was: human agents acting according to the interests, conceptions and (subjective) constraints of majority leaders. ABCFM members took the strength and motivation for their occasionally risky stand from their belief in the Gospel and their identification with the Enlightenment (Enlightenment not in the French, but in a specific Anglo-American Protestant understanding that combined religious millennialism and modern progress). They gave humanitarian and spiritual assistance, and left important testimonies. But they were not able to reverse the outcome of the forceful policies in question. At the Peace Conference in Paris in 1919, area expert Clarence Ussher, a former ABCFM missionary in Van, pleaded in vain for the systematic repatriation of Armenian survivors and Kurdish refugees (Kieser 2000: 545-46). 
[59] Be it many years later, acts of forceful removal or destruction demand responsibility, response and, at least symbolic, reparation. We may this call human reality, wisdom or justice. If the Indians 'are finally ejected from their patrimonial inheritance by arbitrary and unrighteous power, the people of the United States will be impeached,' Evarts had written in 1830. Sometimes old truths can only much later be openly confirmed. In this logic we may understand the official words at the 175th Anniversary of the Establishment of the Bureau of Indian Affairs on 8 September 2000:

[60] 'Let us begin by expressing our profound sorrow for what this agency has done in the past. [...] On behalf of the Bureau of Indian Affairs, I extend this formal apology to Indian people for the historical conduct of this agency. And while the BIA employees of today did not commit these wrongs, we acknowledge that the institution we serve did. We accept this inheritance, this legacy of racism and inhumanity. And by accepting this legacy, we accept also the moral responsibility of putting things right. [...] Never again will we be complicit in the theft of Indian property' (Kevin Gover, Assistant Secretary-Indian Affairs Department of the Interior, quoted in Ellis 2003: 246-47).

[61] 'Everyone judges the westward removal of eastern Indians as one of the great injustices in United States history,' a recent American textbook states. Turkish textbooks will have to use stronger terms with regard to the Armenians. Indian removal, like the Armenian removal, evolved in a complex, but fast way 'from an unthinkable scheme to accepted policy.' The acceptance of removal, and of genocide, is a story 'of greedy men who lied so convincingly that they themselves came to believe their deceits,' but also of people who risked 'their lives and reputations for decency and justice' (Heidler 2007: 1). 


\section{References}

Akçam, Taner (2006) A shameful act: the Armenian genocide and the question of Turkish responsibility, New York, Metropolitan Books.

Andrew III, John A. (1992) From revival to removal. Jeremiah Evarts, the Cherokee nation, and the search for the soul of America, Athens Georgia, University of Georgia Press.

Bloxham, Donald (2005) The great game of genocide: imperialism, nationalism, and the destruction of the Ottoman Armenians, Oxford, Oxford University Press.

Bozarslan, Hamit (1997) 'Histoire des relations arméno-kurdes', in H.-L. Kieser (ed.), Kurdistan und Europa, Zürich, Chronos, p. 151-186.

Carter, Kent (n.d.) Wantabes and Outalucks: Searching for Indian Ancestors in Federal Records, http://www.archives.gov/genealogy/heritage/native-american/ancestor-search.html, accessed 23 Jan. 2008.

Davison, Roderic H. (1990) Essays in Ottoman and Turkish History, 1774-1923. The impact of the West, Austin, University of Texas Press.

Dündar, Fuat (2006) L'ingénierie ethnique du Comité Union et Progrès et la Turcisation de I'Anatolie, unpublished doctoral dissertation, Paris, EHESS.

Ellis, Richard E. (2003) Andrew Jackson, Washington DC, CQ Press. Reproduces many documents, among them the speech of Kevin Gover of 8 September 2000, <http://www.twofrog.com/gover.html>, accessed 10 Jan. 2008.

Bradley, Harold (2008) 'Jackson, Andrew', Encyclopædia Britannica Online, http://search.eb.com/eb/article-9043159, accessed 9 Jan. 2008.

Evarts, Jeremiah (1981) Cherokee removal: the 'William Penn' essays and other writings, ed., with an intr. by Francis Paul Prucha, Knoxville, Univ. of Tennessee.

Grabill, Joseph L. (1971) Protestant Diplomacy and the Near East. Missionary Influence on American Policy, 1810-1927, Minnesota, University of Minnesota Press.

Hanioğlu, M. Şükrü (2008) A brief history of the late Ottoman empire, Princeton, N.J., Princeton University Press. 
Harper, Susan B. (2003) 'Mary Louise Graffam: witness to genocide', in Winter, Jay (ed.), America and the Armenian Genocide of 1915, Cambridge, Cambridge University Press, p. 214-39.

Heidler, David S.; Heidler, Jeanne T. (2007) Indian Removal, New York, W.W. Norton.

Hill, Sarah H. (2005) Cherokee Removal: Forts Along the Georgia Trail of Tears, draft report, The National Park Service and the Georgia Department of Natural Resources/Historic Preservation

Division, $<$ http://www.nps.gov/archive/trte/TRTE/Georgias\%20Trail\%20of\%20Tears\%20Report\%200N LY.pdf>, accessed 10 Jan. 2008.

Jenkins, Paul (2000) 'The Church Missionary Society and the Basel Mission: an early experiment in inter-European co-operation', in Ward, Kevin; Stanley, Brian, The Church Missionary Society and World Christianity 1799-1999, Grand Rapids, William B. Eerdmans, p. 42-63.

Kaiser, Hilmar (2001) At the crossroads of Der Zor. Death, survival, and humanitarian resistance, Princeton N. J., Taderon.

Kaligian, Dikran Mesrop (2003) The Armenian Revolutionary Federation under Ottoman constitutional rule, 1908-1914, unpublished doctoral thesis, Boston College.

Kévorkian, Raymond H. (2006) Le génocide des Arméniens, Paris , O. Jacob.

Kieser, Hans-Lukas (2000) Der verpasste Friede. Mission, Ethnie und Staat in den Ostprovinzen der Türkei 1839-1938, Zurich, Chronos.

Kieser, Hans-Lukas (2002) 'Dr Mehmed Reshid (1873-1919): A political doctor', in: H.-L. Kieser and D. Schaller (eds.), The Armenian Genocide and the Shoah / Der Völkermord an den Armeniern und die Shoah, Zürich, Chronos, p. 245-79.

Kieser, Hans-Lukas (2005) 'Deplorable, unavoidable, functional, salutary: Some remarks on the acceptance of mass violence by Turkish and German elites in the context of the Armenian genocide', Bridges 12-1/2, p. 189-227.

Kieser, Hans-Lukas (2007) A quest for belonging. Anatolia beyond empire and nation (19th21st c.), Istanbul, Isis. 
Kieser, Hans-Lukas (2008) 'Removal of American Indians, destruction of Ottoman Armenians. American missionaries and demographic engineering', European Journal of Turkish Studies, Thematic Issue N ${ }^{\circ} 7$, No. 7 | Demographic Engineering - part I, URL : http://www.ejts.org/document2873.html html To quote a passage, use paragraph (§).

Lewy, Guenter (2004) 'Were American Indians the Victims of Genocide?', History News Network, originally published in Commentary, http://hnn.us/articles/7302.html, accessed 19 Jan. 2008.

Mikusch, Dagobert von (1929) Gasi Mustafa Kemal zwischen Europa und Asien. Eine Lebensgeschichte, Leipzig, Paul List.

Mooney, James ([1897-1898] 1996) Myths of the Cherokee, Mineola NY, Dover.

Niebuhr, Helmut Richard (1988, first edition 1938) The kingdom of God in America, Middletown, Wesleyan University Press.

Thornton, Russell (1990) The Cherokees: a population history, with the assistance of C. Matthew Snipp and Nancy Breen, Lincoln (Neb.), University of Nebraska Press.

Parsons, Levi ([1824] 1830) Memoir of Levi Parsons, first missionary to Palestine from the United States, compiled and prepared by Rev. Daniel O. Morton, Hartford Con., Cook \& Co. and Packard \& Butler.

Phillips, Clifton Jackson (1969) Protestant America and the pagan world: the first half century of the American Board of Commissioners for Foreign Missions, 1810-1860, Boston, Harvard University Press.

Riggs, Henry H. (1997) Days of Tragedy in Armenia. Personal Experiences in Harpoot, 19151917, Michigan, Gomidas Institute.

Verheij, Jelle (1999) 'Die armenischen Massaker von 1894-1896. Anatomie und Hintergründe einer Krise', in H.-L. Kieser ed.), Die armenische Frage und die Schweiz (1896-1923) / La question arménienne et la Suisse (1896-1923), Zürich, Chronos, p. 69-129.

Wiessner, Gunnar (1997) Hayoths Dzor - Xavasor. Ethnische, ökonomische und kulturelle Transformation eines ländlichen Siedlungsgebietes in der östlichen Türkei seit dem 19. Jahrhundert, Wiesbaden, Dr. Ludwig Reichert Verlag.

Wilentz, Sean (2005) Andrew Jackson, New York, Times Books.

Wyeth, Walter N. (1896) Poor Lo! Early Indian missions. A memorial, Philadelphia, Pa., W.N 